\title{
Evaluation of Information Technology Governance in the Application of Smart City in Bandung City Government-Indonesia
}

\author{
Muhammad Rozahi Istambul*, Egi Abinowi \\ Department of Information System, Widyatama University, Indonesia
}

Copyright@2019 by authors, all rights reserved. Authors agree that this article remains permanently open access under the terms of the Creative Commons Attribution License 4.0 International License

\begin{abstract}
Smart City is a service that utilizes information technology for the community that can be built and developed in a government, especially in the city of Bandung-Indonesia. However, the success of a Smart City is very dependent on optimal planning and implementation plus good governance. Therefore, the technology products produced from the use of information technology must also be able to provide comfort and satisfaction for the community in which Smart City is applied. To ensure that Smart City has produced outputs and outcomes that have been successfully built and implemented, it is necessary to evaluate the extent to which information technology governance has been carried out from the beginning of planning to the application or use in the community.
\end{abstract}

Keywords Evaluation, Governance, Information Technology, Smart City

\section{Introduction}

Information Technology is a supporter of the goals and objectives of an organization, in order to provide more useful services for the city community, one of the efforts of the city government is to build Smart City. Smart City consists of several parts, including; Smart Economy, Smart Mobility, and Smart Government. The goal of Smart City is to provide efficient service in a sustainable manner and provide a sense of security for the community as the views on Smart City include service, public policy-making, and planning (Patel \& Padhya, 2014).

The Smart City Information System is a necessity for community services that can provide convenience in administration and city needs to serve the community. With the implementation of Smart City information system in the city of Bandung, it is expected that service to the community will become much better. Besides that, parties related to the government administration process have become better in managing data governance and meeting the needs of the community.

Smart City is very much in line with the view on Smart Government, which is one of the important elements of the city regarding government agencies/institutions that are developed based on the functions of information technology so that they can be accessed by interested parties effectively and efficiently (Bappenas, 2015). As a comparison material, the Singapore government makes a Smart Government plan by setting the level of capability as the main indicator (Delloite, 2015). Therefore, the development of Smart City is expected to encourage the formation of a government system that is transparent, integrated, and has better accountability. This research was conducted to evaluate a number of information technologies that have been developed in the city of Bandung and assess the extent to which governance has been widely carried out.

This study uses COBIT-5 references in evaluating governance in the Governance and Management field. Data from the Smart City of Bandung, especially in the field of Smart Government that supports Governance and Management obtained from the Office of Communication and Informatics of Bandung City Government (Dinas Komunikasi dan Informatika Pemerintah Kota Bandung), were used as data sources.

\section{Methodological Research}

Smart City according to IBM is a way to use information and communication technology to feel, analyze, and integrate various important information from the main system in carrying out city activities. At the same time, Smart City can make intelligent responses to various types of needs, including daily livelihoods, environmental protection, public safety and city services, to industrial and 
commercial activities (Qin, Li, \& Zhao, 2010).

In short, Smart City is the true approach of Smart Planet that applies to certain regions that include informative and integrated city management. This can also be said as effective integration of smart planning ideas, smart construction modes, smart management methods, and smart development approaches. Through the management of digital grids of urban geography, resources, environment, economy, social and other systems, as well as digital and informative processing and application of urban and environment infrastructure, we can achieve intelligent urban management and services, thus promoting a more efficient, more comfortable, and harmonious modern city operations ( $\mathrm{Su}, \mathrm{Li}, \& \mathrm{Fu}, 2011$ ).

Intelligent governance is described as an important parameter of Smart City which is based on citizen participation and private or public partnerships (Odendaal, 2003). A number of success factors of an eGovernment (e-Gov) are seen from the point of view of law, regulation, as well as institutions and the environment that comes from the idea of the government. The use of Smart City faces similar challenges that affect policy issues. Government policies are implemented and operated based on formal rules or certain groups of rules, as in the Smart City framework which consists of six main parts, namely; smart economy, smart people, smart governance, smart mobility, smart environment, and smart living. Their operational definitions of intelligent economics include factors around economic competitiveness as innovation, entrepreneurship, trademarks, productivity, and labor market flexibility, as well as integration in national and global markets. (H., et al., 2012).

Audit professionals need guidance in carrying out their activities in the face of an increasingly automated environment, such as the initial development of COBIT as a framework for implementing information technology audit assignments (De Haes, Van Grembergen, \& Debreceny, 2013). According to ISACA, COBIT 5 provides a comprehensive framework that helps companies achieve their goals to incorporate information technology management and governance. COBIT 5 enables information technology to be managed comprehensively for all organizations, including in the field of business responsibility and functional information technology as a whole and taking into account the interests of internal and external stakeholders related to information technology (Kasey, 2017).

The research stages in evaluating governance on Smart City in Bandung, in addition to referring to the methodology developed in COBIT, are generally carried out as follows:

- Data collection based on applications and technology including data that can be monitored by the community
- Survey of access from the community and management carried out by the city government of Bandung

- Interviews with the head of Bandung City Government in the information and communication technology policy section, including the data verification section that researchers have evaluated

- Study documents that can be shared according to permissions

Whereas in the governance and management framework in COBIT 5, there are five stages which are carried out as follows:

a) Evaluate, Direct, and Monitor

b) Align, Plan, and Organize

c) Build, Acquire, and Implement

d) Deliver, Service, and Support

e) Monitor, Evaluate, and Assess

\section{Analysis and Discussion}

Smart City in Bandung city applies the E-Government technology trend in Smart Governance which according to Gartner consists of 10 top strategies (Kasey, 2017). However, our evaluations were mapped in only 4 phases which were adjusted to the top 10 trends of the strategy previously mentioned. The evaluation of the mapped phase, namely:

- $\quad$ Phase 1 includes: digital workplace and multichannel citizen engagement

- Phase 2 includes: open any data, citizen e-ID, the analytics everywhere, and smart machines

- Phase 3 includes: internet of things, digital government platforms, and software-defined architecture

- $\quad$ Phase 4 includes: risk-based security

So it can be concluded that the relationship between a phase to the next phase is very close and interdependent, including between levels within the same phase. The following is an image of each mapped phase.

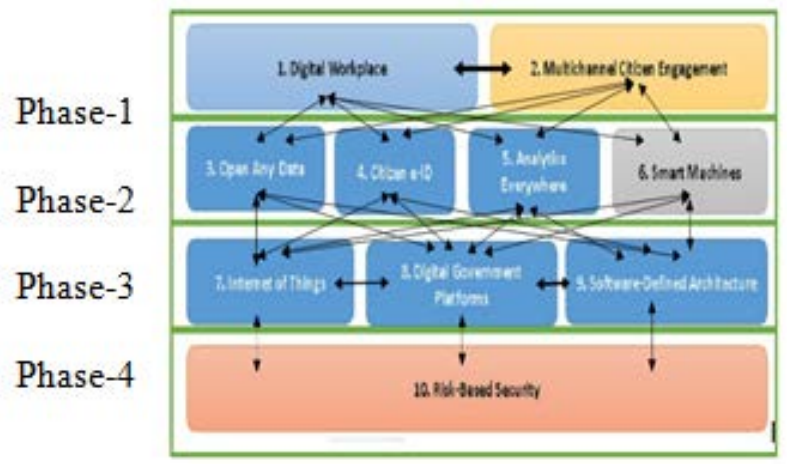

Figure 1. Trend mapping in each phase 
Phase 1 consists of digital workplace and multichannel citizen engagement, in this case, the two trends have connectivity and can influence each other towards the trend where each trend in Phase 1 also has involvement with each trend in Phase 2, meanwhile, each trend in Phase 2 are independent and do not influence each other. Phase 2 consists of open data, citizen e-ID, the analytics everywhere, and smart machine, which will then affect phase 3. Phase 3 also has mutual connections between trends in the same phase. Phase 3 consists of the internet of things, digital government platforms, and software-defined architecture. Each trend in Phase 3 also has involvement in the phase 4 trend consisting of risk-based security. Thus, the risk-based security trend covers all risks and security in all trends in previous phases.

\subsection{Evaluation Phase-1}

Digital workplace with technology support that positions the workspace as a digital media to carry out so many activities access makes it easy for various parties to carry out their activities. Although there are still direct (face-to-face) meetings, the face-to-face meetings can reduce the number of meetings that actually spend time and queues. The digital workplace that uses information technology is a supporting media for building a social work environment. The application of the digital workplace that is applied to Smart City in the city of Bandung has a social connection where the activities can be connected with multichannel citizen engagement that is a user of the digital workplace and the intended user is a community in the city of Bandung. Since both of them are interconnected, then if multichannel citizen engagement is not optimally utilized by the community as the purpose of using government services by the community, then the digital workplace cannot fully benefit from the existence of smart city services provided in accordance with the expected goals even though the digital workplace is already very satisfying in the trend evaluation.

Multichannel citizen engagement is a form of community collaboration with the government through means and communication media. However, the results of the evaluation of multichannel citizen engagement trends found that there was a lack of socialization and training conducted by the Bandung City government towards the user community. This causes people not to care about using e-Gov technology that is already available in the Smart City Government of Bandung.

\subsection{Evaluation Phase-2}

In the open data trend, Bandung City Government has implemented it through e-Gov Smart City with a number of survey and summary data from the government aimed at public consumption and aims to prove the transparency and accountability of the performance of the Bandung City
Government, as well as information feedback from the community to the government to jointly build something useful. Evaluation of this trend is quite good because feedback from the community can be immediately accepted even though it is still not optimal in terms of the percentage of people in Bandung.

In the citizen e-ID trend, Bandung City Government through E-Gov Smart City has implemented the provision of an ID that is unique to each person in the community. Community IDs are associated with IDs on identity cards (KTP) and family cards (KK) that have been physically owned by the community before Smart City was developed and have been recorded in the respective sub-district database. Evaluation of this trend went well because it directly managed to connect the database in the sub-districts with the Smart City database.

With the trend of analytics everywhere, Bandung City Government through Smart City E-Gov can interact and exchange data/information in real-time, including the incidence of some situational contexts which can change over time. Evaluation of this trend is quite good because the current situation of the community regarding some problems can be informed directly to the government so that it can be immediately followed up. Evaluation of this trend was also identified quite well because there were not many people who did not use it due to lack of socialization.

The smart machine trend in e-Gov Smart City in Bandung City Government is a supporting infrastructure for various systems in the Smart City Government of Bandung. Bandung City Government through e-Gov Smart City has implemented smart machines in routine activities that make it easier, practical, and orderly. This is evidenced by the existence of electronic parking systems and traffic light arrangements that are accompanied by CCTV devices. However, the smart machine of the Bandung City Government through Smart City e-Gov has not fully worked as expected, despite receiving satisfactory feedback from the community. This is caused by the limited number of human resources owned by the Bandung City Government in operating and controlling its monitoring devices. Likewise, there are still a number of smart machine devices that have not been held/implemented resulting in less optimal service. Evaluation of this trend shows that the limited procurement of devices that have been planned but are not yet available has disabled the system to be fully optimized.

\subsection{Evaluation Phase-3}

Internet of things is a combination of physical and digital components to produce a model. With the increasingly efficient and reliable management of information technology, the functions and capabilities of technology can be digitized (Wortmann \& Flüchter, 2015). In the Bandung City Government's E-Gov Smart City, the concept of the internet of things helps connect devices used 
in phase 2 trends, phase 4 trends, and between phases 3 . Evaluation of this trend is also quite good at utilizing existing technology.

The digital government platform trend is a digital platform, in the form of mobile, desktop and other web-based applications, which is aimed at public services in Bandung City Government. In the e-Gov Smart City Bandung City Government, the government can serve the community with the support of technology that is interconnected through digital platforms, which include payment, licensing, basic verification, and other public services. Evaluation of this trend is quite good with various applications built for easy access of information data and transactions.

Trend software-defined architecture is an architecture that inserts an intermediary (middleware) as a link to the final service (requestor) with the service developer (provider). With the software-defined architecture of the e-Gov Smart City Bandung City Government, obviously, there is an integrated system architecture design software development, which starts from the planning of software development, goals, to the structure of the system within Bandung's e-Gov Smart City, including planning to the current system. This will make it easier for developers to develop the system in the future. Evaluation of this trend is good with the availability of a blueprint for developing software.

\subsection{Evaluation Phase-4}

The risk-based security trend in e-Gov Smart City Bandung City Government is a key phase of all existing phases, so this trend is the foundation of all previous trends. This trend is an aspect that really needs to be considered because it greatly affects the risk aspects, governance, data migration, and security of the e-Gov Smart City Bandung City Government. However, there are still shortcomings in standard setting according to standard guidelines. This is reflected in making data records, such as records of actions that have occurred, including other supporting data. There are many aspects that are less noticed, such as lack of awareness in monitoring (validity period), optimizing, and reporting performance where portfolios (actions) of several applications and certificates in the maintenance of many data are less well organized in some places. All of this is due to the absence of good governance guidelines in carrying out preventive and corrective actions.

\section{Results}

Results of the evaluation of Smart City governance in Bandung City Government using COBIT 5 obtained a number of findings, namely:

- Monitor, optimize and report on investment portfolio performance (APO 05.04), findings: lack of awareness in monitoring (validity period), optimizing and reporting performance where portfolios (actions) several applications and certificates become part of an investment,

- $\quad$ Maintain portfolio (APO 05.05), finding: data under maintenance are less structured and become unmanaged in several places,

- Define a risk management action portfolio (APO 12.05), finding: in some applications that are connected with Smart City, especially in E-Gov, we found a lack of explanation in the storage of portfolio of actions that have occurred in risk management,

- Establish and maintain an ISMI (APO 13.01), findings: In the Department of Communication and Informatics of Bandung city government (Dinas Komunikasi dan Informatika Pemerintah Kota Bandung), the appropriate standards have not been met in the establishment and there is a lack of maintenance and governance of information security management systems,

- $\quad$ Close a BAI program (01.14), finding: because some systems are not well socialized, the systems are not optimally used by the community. This resulted in the available systems not being fully utilized by the community.

\section{Conclusions}

This conclusion provides an overview of the focus of improvement in the development of Smart City that not only prepares technology and information but also requires a good information technology governance and guarantees all Smart City's vision that is expected to be achieved optimally (Jabarullah et al., 2019). As a compliment, the city government not only makes information technology blueprints up to socialization issues, but also needs to maximize the provision of technological capabilities that include human resource, organizational and management capabilities, facilities, processes, and output-outcome products.

\section{REFERENCES}

[1] Bappenas. (2015). Laporan Tujuan Pembangunan Millenium di Indonesia 2014. Jakarta.

[2] De Haes, S., Van Grembergen, W., \& Debreceny, R. (2013). COBIT 5 and enterprise governance of information technology: Building blocks and research opportunities. Journal of Information Systems, 27(1), 307-324.

[3] Delloite. (2015). Smart Cities: How rapid advances in technology are reshaping our economy and society. Amsterdam: Touch Tohmatsu Limited (DTTL).

[4] H., C., Nam, T., Walker, S., Gil-Garcia, J., Mellouli, S., 
Nahon, K., Scholl, H. (2012). Understanding smart cities: An integrative framework. 45th Hawaii International Conference System Science (HICSS) (pp. 2289-2297). IEEE.

[5] Jabarullah, N.H., Shabbir, M.S., Abbas, M., Siddiqi, A.F. \& Berti, S. (2019) Using random inquiry optimization method for provision of heat and cooling demand in hub systems for smart buildings, Sustainable Cities and Society, https://doi.org/10.1016/j.scs.2019.101475.

[6] Kasey, P. (2017, October 3). Gartner Top 10 Strategic Technology Trends for 2018. Retrieved from Smarter with Gartner: https://www.gartner.com/smarterwithgartner/gart ner-top-10-strategic-technology-trends-for-2018/

[7] Odendaal, N. (2003). Information and communication and local governance: Understanding the difference between cities in developed and emerging economies. Computers Environment and Urban Systems, 27, 585-607.

[8] Patel, P. R., \& Padhya, H. (2014). Review Paper for Smart City. International Journal of Advanced Research in Engineering, Science and Management, 1-6.

[9] Qin, H., Li, H., \& Zhao, X. (2010). Development Status of Domestic. Global Presence 9, 50-52.

[10] Su, K., Li, J., \& Fu, H. (2011). Smart city and the applications. International Conference on (pp. 1028-1031). IEEE.

[11] Wortmann, F., \& Flüchter, K. (2015). Internet Of Things. Business \& Information Systems Engineering, 221-224. 